\title{
Impact of troponin I on outcome of ischemic stroke patients
}

\author{
HRVOJE BUDINCEVIC ${ }^{1,2}$, JOSIP SREMEC ${ }^{1}$, PETRA CRNAC ${ }^{1}$, VEDRAN OSTOJIC $^{3}$, EDVARD GALIC $^{2,4}$, IVAN BIELEN $^{1,2}$ \\ ${ }^{1}$ Stroke and Intensive Care Unit, Department od Neurology, Sveti Duh University Hospital, Zagreb, Croatia \\ ${ }^{2}$ School of Medicine, J.J. Strossmayer University of Osijek, Osijek, Croatia \\ ${ }^{3}$ Department of Immunology, Alergology and Pulmonology, Sveti Duh University Hospital, Zagreb, Croatia \\ ${ }^{4}$ Department of Cardiology, Sveti Duh University Hospital, Zagreb, Croatia
}

\begin{abstract}
Introduction. Stroke is one of the leading causes of morbidity and mortality. Cardiac troponins have been found to be increased in other conditions apart from the cardiac diseases, such as stroke. The aim of the study was to assess the correlation between elevated troponin I levels and stroke outcome.

Methods. This retrospective study included 198 acute ischemic stroke patients in whom troponin I levels have been obtained at admission. Exclusion criteria were concomitant acute coronary syndrome, congestive heart failure, pulmonary embolism, renal failure, rhabdomyolysis and septic conditions.

Results. There was a statistically significant difference in the proportion of deaths during hospitalization $(p=0.041)$ and modified Rankin Scale scores $(p=0.016)$ between the group of patients with elevated troponin I levels and the control group. Prior ischemic strokes were more common in the group with elevated troponin I levels $(p=0.032)$. No other differences were observed.

Conclusions. Our study showed that patients with elevated initial troponin I levels are associated with unfavorable outcome or death. Stroke may be associated with mild elevation of troponin levels, contrary to higher levels which are usually related to other conditions.
\end{abstract}

Keywords: outcome, stroke, troponin.

\section{INTRODUCTION}

Cardiovascular disease is the leading cause of death in Europe [1]. Stroke is a leading cause of disability and the third cause of mortality in the world; central and particularly eastern European countries still have high incidence and prevalence of stroke $[2,3]$.

Cardiac troponins are regulatory proteins unique and completely specific to the myocardium, and are an ideal marker of myocardial damage due to their extremely low circulating levels in normal individuals [4]. Cardiac troponin is nowadays central to the definition of acute myocardial infarction (MI) in the consensus guidelines from several major organizations [5]. Although the elevation of cardiac troponins in the blood indicates the presence of myocardial necrosis, the underlying mechanism of necrosis is not certain, as elevated troponin levels can be present in various other clinical conditions causing predominantly nonischemic myocardial injury [5]. The correlation between elevated cardiac troponin levels and stroke outcome has not been elucidated thoroughly yet.

The aim of our study was to assess the correlation between increased troponin I levels and outcome in stroke patients.

\section{METHODS}

This retrospective study included consecutive patients with acute ischemic stroke who were admitted to the Department of Neurology, Sveti Duh University Hospital, Zagreb, Croatia, from 2007 to 2010 in whom troponin I levels were obtained on admission (up to 72 hours after stroke symptoms). The cut-off point for increased levels was set at $0.5 \mu \mathrm{g} / \mathrm{L}$. Patients were divided into two groups according to troponin I cut-off point: group with normal troponin I levels $(<0.5 \mu \mathrm{g} / \mathrm{L})$ and group with elevated troponin I levels $(\geq 0.5 \mu \mathrm{g} / \mathrm{L})$. The local ethics committee approved the study.

Patients were assessed using standard clinical and radiological methods. Data on patients' comorbidities and ischemic stroke subtype according to TOAST classification were collected. Stroke outcome was assessed using modified Rankin Scale (mRS) at hospital discharge and in-hospital mortality data. Unfavorable outcome is defined by a mRS score $>2$.

Exclusion criteria were concomitant acute coronary syndrome, severe congestive heart failure, pulmonary embolism, renal failure, rhabdomyolysis and septic conditions (sepsis, endocarditis, myocarditis...). 
All data was analyzed using Microsoft Excel, and Fisher's exact test, t-test and other values were obtained where necessary using GraphPad.

\section{RESULTS}

The troponin I levels were obtained at admission for 198 patients. In the group with elevated troponin I levels were 10 cases $(5.05 \%)$, mean $1.70 \pm 1.54 \mathrm{ng} / \mathrm{mL}$, and median $1.24 \mathrm{ng} / \mathrm{mL}$. Mean value in the group with normal troponin I levels was $0.05 \pm 0.03 \mathrm{ng} / \mathrm{mL}$, median $0.03 \mathrm{ng} / \mathrm{mL}$. There were only two patients excluded from the study because of simultaneous stroke and acute coronary syndrome. Their troponin values were 3.09 and 64.12 , respectively. Table 1 shows some of the patients' characteristics. No statistically significant differences were found between groups regarding age, gender, stroke risk factors and subtypes, while there was a statistically significant difference in the proportion of prior ischemic stroke between two groups, as they were more common in the group with elevated troponin I levels. There was a statistically significant difference in modified Rankin Scale scores (mRS) and in-hospital mortality between the groups (Table 2).

Table 1

Risk factors for stroke in both of the patient groups

\begin{tabular}{|l|c|c|c|c|}
\hline & $\begin{array}{c}\text { All patients } \\
\mathbf{N = 1 9 8}\end{array}$ & $\begin{array}{c}\text { Normal troponin levels } \\
\mathbf{N = 1 8 8}\end{array}$ & $\begin{array}{c}\text { Elevated troponin levels } \\
\mathbf{N}=\mathbf{1 0}\end{array}$ & p-value \\
\hline Age (years) - Mean \pm standard deviation & $72.45 \pm 10.69$ & $72.16 \pm 10.78$ & $77.80 \pm 6.72$ & 0.105 \\
\hline Arterial hypertension (n, \%) & $168 ; 85 \%$ & $161 ; 86 \%$ & $8 ; 80 \%$ & 0.642 \\
\hline Diabetes mellitus (n, \%) & $68 ; 34 \%$ & $67 ; 36 \%$ & $1 ; 10 \%$ & 0.169 \\
\hline Hyperlipidemia (n, \%) & $112 ; 57 \%$ & $109 ; 58 \%$ & $3 ; 30 \%$ & 0.106 \\
\hline Atrial fibrillation (n, \%) & $75 ; 38 \%$ & $70 ; 37 \%$ & $5 ; 50 \%$ & 0.508 \\
\hline Prior ischemic stroke (n, \%) & $56 ; 28 \%$ & $50 ; 27 \%$ & $6 ; 60 \%$ & 0.032 \\
\hline TOAST classification (n, \%) & & & $5 ; 50 \%$ & 0.519 \\
Cardiac embolism & $78 ; 39 \%$ & $73 ; 39 \%$ & $5 ; 50 \%$ & 0.743 \\
Large artery disease & $81 ; 41 \%$ & $76 ; 40 \%$ & 0 & 0.215 \\
Small artery disease & $39 ; 20 \%$ & $39 ; 21 \%$ & & \\
\hline
\end{tabular}

Table 2

Stroke outcome in both of the patient groups

\begin{tabular}{|l|c|c|c|c|}
\hline & $\begin{array}{c}\text { All patients } \\
\mathbf{N = 1 9 8}\end{array}$ & $\begin{array}{c}\text { Normal troponin levels } \\
\mathbf{N}=\mathbf{1 8 8}\end{array}$ & $\begin{array}{c}\text { Elevated troponin levels } \\
\mathbf{N}=\mathbf{1 0}\end{array}$ & p-value \\
\hline mRS (discharge) - mean \pm standard deviation & $3.515 \pm 1.77$ & $3.441 \pm 1.76$ & $4.900 \pm 1.37$ & 0.016 \\
\hline mRS (discharge) $>2(\mathrm{n}, \%)$ & $122 ; 62 \%$ & $113 ; 60 \%$ & $9 ; 90 \%$ & 0.092 \\
\hline In-hospital mortality (n, \%) & $43 ; 22 \%$ & $38 ; 20 \%$ & $5 ; 50 \%$ & 0.041 \\
\hline
\end{tabular}

mRS - modified Rankin Scale

\section{DISCUSSION}

In our study, we found a statistically significant association between increased troponin I levels and adverse outcome, in both higher in-hospital mortality and higher modified Rankin Scale score at hospital discharge. Stroke poses an increased risk for electrocardiographic changes, cardiac arrhythmias, and myocardial cell damage [6]. It has been shown that highly specific myocardial necrosis markers such as troponin can be increased in stroke victims, a phenomenon that has been explained by several pathophysiologic mechanisms: primary cardiac damage with secondary cardioembolic cerebral ischemia or primary cerebral ischemia with secondary cardiac damage caused by increased levels of catecholamines (caused by sympathetic system activation) [7-10]. Some studies associate increased troponin levels with a certain localization of stroke: insular or right hemisphere [11-13]. Atrial fibrillation is more likely to be diagnosed after a detailed evaluation in patients with troponin increase [14].

The proportion of stroke patients with cardiac troponin level increase varies in several studies from $9.73 \%$ to $20.6 \%[11,12,15]$. However, a smaller proportion of patients had increased troponin I levels in our study probably because higher cut-off levels were used. The lack of difference between the groups in our study in the proportion of patients diagnosed with atrial fibrillation could be explained with insufficient follow-up, or the fact that some of the patients who possibly had atrial fibrillation died before it could be verified. 
These findings are consistent with a previous study by Lasek-Bal et al., who have found that elevated levels of troponin I are present in less than $10 \%$ of patients, and these patients were associated with an unfavorable course of stroke leading to significant disability and less independence in their activities of daily living. In their study the cut-off level for troponin I was $0.014 \mathrm{ng} / \mathrm{mL}$ [11]. Scheitz et al.'s study has found that the elevation of troponin $\mathrm{T}$ levels occurs in every seventh patients with acute ischemic stroke and is indepedently associated with poor short-term outcome measured by $\mathrm{mRS}(\mathrm{mRS}>2)$ and in-hospital mortality [15]. Furthermore, elevated troponin levels are associated with an almost 2-fold increased risk of 5-year mortality [16]. In concordance with our study several studies showed that the short-term and long-term unfavorable outcome has been associated with increased troponin levels [6, 11, 12, 15-17].

As opposed to levels of troponin I elevation found in our study, cardiac causes of troponin elevation are usually associated with higher troponin I levels [18].
Several prior studies have shown inconsistent results: a considerable number of previous studies showed similar, as well as discordant findings and results for most parameters assessed in this study. The limitations of our study include the fact that it is a single center study, and that we were not focused on initial stroke severity. Caution is needed when interpreting the result due to a relatively small number of patients, and a possible selection bias inherent to the way participants were enrolled.

\section{CONCLUSION}

Our study showed that patients with high initial troponin I levels are associated with unfavorable outcome or death. Further investigation is necessary to clearly show the association of troponin I levels and stroke outcome. Stroke may be associated with mild elevation of troponin levels, contrary to higher levels which are usually related to other conditions.

Acknowledgements. None.

Conflicts of interests. The authors declare that there are not conflicts of interest.

Introducere. Atacul vascular cerebral ischemic este una din principalele cauze de morbiditate si mortalitate. Troponinele cardiace pot creşte şi în alte patologii extracardiace aşa cum este și atacul vascular cerebral ischemic. Obiectivul studiului a fost de a analiza asocierea dintre nivelurile crescute ale tropninei I şi prognosticul AVC-ului ischemic.

Materiale şi Metode. A fost realizat un studiu retrospectiv pe 198 de pacienți cu AVC ischemic cărora le-au fost dozate valorile troponinei I in momentul internării. Au fost excluşi pacienți cu sindrom coronarian acut, insuficiență cardiacă congestivă, embolie pulmonară, insuficiență renală, rabdomioliză sau sepsis.

Rezultate. Între pacienții cu niveluri crescute ale troponiei I şi cei cu niveluri normale a fost o diferență semnificativă în privința mortalității $(p=0.041)$ şi a scorului modificat Rankin $(p=0.016)$. Pacienții cu valori crescute ale troponinei I au avut mai frecvent episoade de AVC în antecedente $(p=0.032)$. Nu au fost observate alte diferențe.

Concluzii. Studiul atestă faptul că pacienții cu AVC ischemic şi valori mari ale troponinelor I se asociază cu deces şi cu un prognostic mai prost. AVC-ul ischemic pare să fie asociat cu niveluri moderate ale troponinelor I comparativ cu alte patologii.

Correspondence to: Hrvoje Budincevic, $\mathrm{MD}, \mathrm{PhD}$

Sveti Duh University Hospital, Department of Neurology, Stroke and Intensive Care Unit,

Sveti duh 64, 10000 Zagreb, Croatia, Tel. +38513712127; fax. +38513712372

E-mail: hbudincevic@gmail.com

\section{REFERENCES}

1. NICHOLS M, TOWNSEND N, SCARBOROUGH P, RAYNER M. Cardiovascular disease in Europe 2014: epidemiological update. Eur Heart J 2014; 35:2929. 
2. LLOYD-JONES D, ADAMS RJ, BROWN TM et al. Heart disease and stroke statistics--2010 update: a report from the American Heart Association. Circulation 2010; 121:e46-e215.

3. BUDINCEVIC H, TIU C, BERECZKI D et al. Management of ischemic stroke in Central and Eastern Europe. Int J Stroke 2015; 10 Suppl A100:125-127.

4. ALPERT JS, MALASKY BR, THYGESEN K. Redefining myocardial infarction for the $21^{\text {st }}$ century. Trans Am Clin Climatol Assoc 2004; 115:79-94; discussion 94-76.

5. THYGESEN K, ALPERT JS, JAFFE AS, SIMOONS ML, CHAITMAN BR, WHITE HD. Third universal definition of myocardial infarction. Glob Heart 2012; 7:275-295.

6. SAMUELS MA. Neurally induced cardiac damage. Definition of the problem. Neurol Clin 1993; 11:273-292.

7. DONNELLY R, MILLAR-CRAIG MW. Cardiac troponins: IT upgrade for the heart. Lancet 1998; 351:537-539.

8. JAMES P, ELLIS CJ, WHITLOCK RM, MCNEIL AR, HENLEY J, ANDERSON NE. Relation between troponin T concentration and mortality in patients presenting with an acute stroke: observational study. BMJ 2000; 320:1502-1504.

9. ETGEN T, BAUM H, SANDER K, SANDER D. Cardiac troponins and N-terminal pro-brain natriuretic peptide in acute ischemic stroke do not relate to clinical prognosis. Stroke 2005; 36:270-275.

10. BARBER M, MORTON JJ, MACFARLANE PW, BARLOW N, RODITI G, STOTT DJ. Elevated troponin levels are associated with sympathoadrenal activation in acute ischaemic stroke. Cerebrovasc Dis 2007; 23:260-266.

11. LASEK-BAL A, KOWALEWSKA-TWARDELA T, GASIOR Z et al. The significance of troponin elevation for the clinical course and outcome of first-ever ischaemic stroke. Cerebrovasc Dis 2014; 38:212-218.

12. SCHEITZ JF, ENDRES M, MOCHMANN HC, AUDEBERT HJ, NOLTE CH. Frequency, determinants and outcome of elevated troponin in acute ischemic stroke patients. Int J Cardiol 2012; 157:239-242.

13. COJOCARU IM, COJOCARU M, SAPIRA V et al. Troponin T changes in acute ischemic stroke. Rom J Intern Med 2014; 52:97-101.

14. BEAULIEU-BOIRE I, LEBLANC N, BERGER L, BOULANGER JM. Troponin elevation predicts atrial fibrillation in patients with stroke or transient ischemic attack. J Stroke Cerebrovasc Dis 2013; 22:978-983.

15. ANDERS B, ALONSO A, ARTEMIS D et al. What does elevated high-sensitive troponin I in stroke patients mean: concomitant acute myocardial infarction or a marker for high-risk patients? Cerebrovasc Dis 2013; 36:211-217.

16. THALIN C, RUDBERG AS, JOHANSSON F et al. Elevated Troponin Levels in Acute Stroke Patients Predict Long-term Mortality. J Stroke Cerebrovasc Dis 2015; 24:2390-2396.

17. SCHEITZ JF, NOLTE CH, LAUFS U, ENDRES M. Application and interpretation of high-sensitivity cardiac troponin assays in patients with acute ischemic stroke. Stroke 2015; 46:1132-1140.

18. LIEBETRAU C, WEBER M, TZIKAS S et al. Identification of acute myocardial infarction in patients with atrial fibrillation and chest pain with a contemporary sensitive troponin I assay. BMC Med 2015; 13:169.

Received June 29, 2016 